\title{
The "developmental conduit" of the tribe Microtini (Rodentia, Arvicolinae): Systematic and evolutionary aspects
}

\author{
Fedor N. Golenishchev \& Vladimir G. Malikov
}

\begin{abstract}
According to the recent data on molecular genetics and comparative genomics of the grey voles of the tribe Microtini it is supposed, that their Nearctic and Palearctic groups had independently originated from different lineages of the extinct genus Mimomys. Nevertheless, that tribe is considered as a natural taxon. The American narrow-skulled voles are referred to a new taxon, Vocalomys subgen. nov.
\end{abstract}

KEY WORDS: homology, homoplasy, phylogeny, vole, Microtini, evolution, taxonomy.

Fedor N. Golenishchev[microtus@zin.ru] and Vladimir G. Malikov [microtus@zin.ru], Zoological Institute, Russian Academy of Sciences, Universitetskaya nab. 1, Saint-Petersburg 199034, Russia.

\section{«Канал развития» полевок трибы Microtini (Rodentia, Arvicolinae): систематико-эволюционный аспект.}

\section{Ф.Н. Голенищев, В.Г. Маликов}

\begin{abstract}
РЕЗЮМЕ. В соответствии с последними данными молекулярной генетики и сравнительной геномики серых полевок трибы Microtini делается вывод о независимом происхождении неарктических и палеарктических групп от разных представителей вымершего рода Mimomys. Несмотря на это, данная триба считается естественным таксоном. Американские узкочерепные полевки выделяются в самостоятельный подрод Vocalomys subgen. nov.
\end{abstract}

КЛЮЧЕВЫЕ СЛОВА: гомология, гомоплазия, филогения, полевки, Microtini, эволюция, таксономия.

\section{Introduction}

The Holarctic subfamily Arvicolinae Gray, 1821 is known to comprise a number of transberingian vicariants together with a few Holarctic forms. Originally, the extent of their phylogenetic relationships was judged on their morphological similarity. Further, the data on comparative cytogenetics and postzygotic reproductive isolation made the taxonomists challenge the systematic position of some microtine forms that had been impossible only on the base of traditional morphology. However, it has not been possible to revise considerably either macroevolutionary scenario of formation of voles' recent diversity or ideas about systematic relationships between the transberingian vicariants without summarized results of different molecular-genetic analyses. The common or the grey voles of the genus $\mathrm{Mi}$ crotus Schrank, 1798 (sensu lato) were usually included together with Arvicola L., 1758 (and sometimes with Ondatra Link, 1795) in the broadly defined tribe Arvicolini (Pavlinov et al., 1995; Pavlinov, 2003). However, molecular data indicate that Arvicola and Microtus are not sister taxa (Conroy \& Cook, 2000). So apart from Arvicola and Ondatra the species of the genus Microtus were lumped together in a tribe Microtini Miller, 1886 (Shenbrot \& Krasnov, 2005) that includes a number of Palearctic forms and their Nearctic ecomorphological vicariants with rootless ever-growing molars and crown cement.
The history of the group in the light of the molecular data

The grey voles are usually altogether regarded as a first-hand descendant of the Early Pleistocene genus Allophaiomys Kormos, 1930, in which molars, like in common voles, had already become rootless. Their primitive dental pattern resembling that of such Central Asiatic living groups of the genus Microtus as subgenera Phaiomys Blyth, 1863, Blanfordimys Argyropulo, 1933, and Neodon Hodgson, 1849 (Gromov \& Polyakov, 1977; Golenishchev \& Sablina, 1991; Nadachowski \& Zagorodnyuk, 1996). Martin \& Tesakov (1998), considering that state of dental morphology as a symplesiomorphy, suggested to include Allophaiomys in Microtus. Allophaiomys, in its turn, is believed to have originated from the Late Pliocene-Early Pleistocene genus Mimomys Major, 1902, in which molars possessed roots, crown cement in inward angles, and negatively differentiated enamel. As far as the latter trait is concerned, among the recent species they are only Microtus (Orthriomys) umbrosus Merriam, 1898 and M. (Herpethomys) guatemalensis Merriam, 1898 which have such kind of dental morphology (Martin, 1998).

Though the diversity of living and extinct Arvicolinae shows that quite often different lineages achieve some similar characters independently of each other (Gromov, 1972; Angerman, 1973; Gromov \& Polyak- 
ov, 1977), the overall common voles' state of morphology is still supposed to have been inherited directly from their hypothetical common ancestor. Most of the taxonomists consider the common voles as Holarctic genus Microtus (Hinton, 1926; Ellerman, 1941; Ellerman \& Morrison-Scott, 1951; Gromov \& Polyakov, 1977; Corbet, 1978; Musser \& Carleton, 2005) that is of a Palearctic origin. According to those authors it is comprised of about 63 species (including 19 Nearctic ones), of 17 subgenera (among which six are New World's endemics, and three are Holarctic ones). In spite of the clear evidence that the striking environmental resemblance between those continents had to cause a strong tendency towards parallel formation, there are some Palearctic microtines, each of them was quite often referred to the same subgenus or even to the same species with its Nearctic morphoecological analogue. Those vicariants (Tab. 1) together with some former ideas about their systematic relationships were listed previously (Golenishchev \& Malikov, 2004).

As regards extinct forms, according to the cladistic analysis Nearctic Microtus pliocaenicus Kormos, 1933 and M. meadensis Hibbard, 1944 were placed in the subgenera Phaiomys and Terricola subsequently (Martin, 1995), as well as Pedomys Baird, 1858 was synonimized under Pitymys s. lato (Martin, 1987), and all advanced voles with T4-5 confluent were lumped in the tribe Pitymyini (Repenning, 1983; Repenning et al., 1990). Then Martin (1995), according to the results of cladistic evaluation of dental morphology, separated
Pedomys from Pitymys and Orthriomys from Phaiomys, having doubts about the natural unity of voles with the pitymyan rhombus. Indeed, neither living nor fossil representatives of any Palearctic taxa with the pitymyan rhombus have ever been known from Asiatic part of Beringia or adjacent regions of North-East Siberia. Nevertheless, Repenning (2001) supposed that some ancient representatives of the subgenus Terricola could have immigrated to North America via Beringia about 800000 years ago.

It has been considered that all the American microtines originated from some Asiatic forms of the genus Microtus, which immigrated to North America via Beringia as three subsequent waves. That supposition seemed to be quite reasoned because of a large amount of data on repeated Pleistocene glaciations that caused sinking of the sea-level and emerging of the Bering Bridge. According to that point of view the first wave reached Laurentia after Blancan V Glaciation about 2.1 Mya (Hoffman \& Koeppl, 1985; Repenning, 2001). In particular Repenning et al. (1990), and initially Martin (1998) supposed that it was Early Pleistocene Allophaiomys deucalion Kretzoi, 1969 (sensu lato), which had a very widespread geographic range throughout Europe and into Siberia, and, thus, could have dispersed to North America where it might have given an origin to M. californicus Peale, 1848, M. umbrosus and M. guatemalensis which are the most archaic extant Nearctic common voles. The immigrants of the second wave were thought to have crossed the Bridge in the Middle

Table 1. The Palearctic and Nearctic species of the common voles, which were believed as closely related.

\begin{tabular}{|c|c|}
\hline Palearctic species & Nearctic species \\
\hline \multicolumn{2}{|c|}{ Semi-aquatic forms } \\
\hline $\begin{array}{c}\text { genus Arvicola Lacepede, } 1799 \\
\text { Arvicola terrestris L., } 1758\end{array}$ & $\begin{array}{l}\text { subgenus Aulacomys Rhoads, } 1894 \\
\text { Microtus (Aulacomys) richardsoni De Kay, } 1842\end{array}$ \\
\hline \multicolumn{2}{|c|}{ Inhabitants of meadows } \\
\hline $\begin{array}{l}\text { subgenus Microtus Schrank, } 1798 \\
\text { M. (Microtus) agrestis L., } 1761\end{array}$ & $\begin{array}{l}\text { subgenus Microtus } \\
\text { M. (Microtus) pennsylvanicus Ord, } 1815 \\
\text { M. (Microtus) chrotorrhinus Miller, } 1894\end{array}$ \\
\hline \multicolumn{2}{|c|}{ Petrophilous forms } \\
\hline genus Chionomys Miller, 1908 & $\begin{array}{c}\text { subgenus Microtus } \\
\text { M. longicaudatus Merriam, } 1888\end{array}$ \\
\hline \multicolumn{2}{|c|}{ The voles of forbs } \\
\hline subgenus Sumeriomys Argyropulo, 1933 & $\begin{array}{c}\text { subgenus Chilotus Baird, } 1857 \\
\text { M. (Chilotus) oregoni Bachman, } 1839\end{array}$ \\
\hline \multicolumn{2}{|c|}{ Semi-subterranean forms } \\
\hline subgenus Terricola Fatio, 1867 & $\begin{array}{c}\text { subgenus Pitymys McMurtria, } 1831 \\
\text { M. (Pitymys) pinetorum Le Conte, } 1830 \\
\text { M. (Pitymys) quasiater Coues, } 1874\end{array}$ \\
\hline \multicolumn{2}{|c|}{ Narrow-skulled voles of tundra-steppe } \\
\hline $\begin{array}{c}\text { subgenus Stenocranius Kastschenko, } 1901 \\
\text { M. (St.) gregalis Pallas, } 1778\end{array}$ & $\begin{array}{c}\text { subgenus Stenocranius } \\
\text { M. (St.) miurus Osgood, } 1901 \\
\text { M. (St.) abbreviatus Miller, } 1899\end{array}$ \\
\hline
\end{tabular}


Pleistocene. They were considered as ancestral to $M$. quasiater Coues, 1874, M. oaxacensis Goodwin, 1966, M. pinetorum, and M. ochrogaster. Martin \& Tesakov (1998) supposed those species to be descendants of $A$. pliocaenicus or its closest relatives, which evolved from early descendants of $A$. deucalion, which had already possessed the positive enamel differentiation. The third, Late Pleistocene portion of Palearctic forms, except M. oeconomus Pallas, 1776 (Lance \& Cook, 1998) and the narrow-skulled forms united in the subgenus Stenocranius, which were considered as quite recent immigrants to the New World, was presumed to be ancestral to all the rest American living Microtuslike voles (Hoffman \& Koeppl, 1985). According to all those versions, the Microtus-like state of the American common voles, as such, had already arisen in their Palearctic ancestors. Alternatively according to the data on protein electrophoresis (Graf, 1982), C-banding patterns (Modi, 1987), nuclear (Modi, 1996), or mitochondrial (Conroy \& Cook, 2000; Jaarola et al., 2004) DNA, and chromosomal localization of some repeated DNA sequences among species of Microtus (Modi et al., 2003) all the Nearctic common voles seem likely to be closer to each other than to most of the Palearctic species. The exception is Iberian relict M. cabrerae Thomas, 1906, which, being of the most archaic dental morphology among the Palearctic forms (Gromov \& Polyakov, 1977), is of a seemingly genomic nearness to the Nearctic species (Conroy \& Cook, 2000; Modi et al., 2003; Jaarola et al., 2004), though without any reliable bootstrap support. The extremely archaic morphology of $M$. cabrerae in combination with its Mediterranean distribution and seeming genomic likeness to the Nearctic common voles shows that the American branch could have deviated from rather basic site of the common ancestral trunk which had been within the Palearctic range yet. As concerns the amount of "molecular-genetic divergence" between the representatives of different Eurasian superclades (Jaarola et al., 2004), it seems likely to be even larger than that between their American ecomorphological vicariants. Anyway, the overall paleonthological and neonthological knowledge combining shows that the common voles' "phenomogenomic" state is a level of evolutionary development. The latter had been independently achieved by the lineages, which were ancestral to the living species and their monophyletic groups. What were those ancestors like? That is the question. The chronology of fossil remains shows that on both of the continents the main ecomorphological types of the living Microtus had been formed by the middle of Pleistocene. In those times the alpine glaciers and the overall environment of NorthEastern Siberia, Alaska and Laurentia would have served as insuperable barriers on the way of the Microtus-like transcontinental migrants, except such highly dispersal or adopted to subarctic conditions species as M. oeconomus and, presumably, M. miurus. Therefore, the arvicolines, which were ancestral to the Nearctic Microtuslike species, could cross the Bridge only during some warmer time, no later than Late Pliocene-Early Pleis- tocene. As concerns the notion about Allophaiomys deucalion as ancestral to American M. umbrosus and M. guatemalensis (Martin, 1998), which are the most archaic living voles with rootless molars, and $A$. pliocenicus, with the positively differentiated enamel, as ancestral to all the Palearctic and Nearctic advanced $\mathrm{Mi}$ crotus-like species (Martin \& Tesakov, 1998; Chalin et al., 1999; Repenning, 2001), there are two general objections to it as follows:

1) The A. deucalion-like form, with somewhat between slightly negative and neutral enamel differentiation does not seem likely to be ancestral to the living $M$. umbrosus with distinctly negative enamel differentiation. The point is that the idea about the reversion is not parsimonious in the frame of the commonly accepted evolutionary model of enamel's differentiation in microtines from negative via neutral to positive; that's why Martin (1998) finally supposed M. umbrosus and, with less probability, M. guatemalensis to have originated from some Mimomys-like ancestor with negatively differentiated enamel;

2) If A. pliocenicus, either as a single species, or a complex of closely related sibling species (Martin \& Tesakov, 1998) had been ancestral to all advanced Microtus-like species with rootless molars and positively differentiated enamel, the data on the molecular genetic and comparative genomic would have shown the latter as two subdivided reliably monophyletic clades, the Palearctic and the Nearctic ones subsequently, which, in turn, would have been the branches of a monophyletic Holarctic superclade of a high bootstrap support. Our mode of thinking about the matter is based on a comparatively recent age of $A$. pliocenicus fossil remains (about 2 Mya) and supposingly few amount of divergence between its forms even if the latter had been distinct species. Nevertheless, judging by the data on molecular genetics and comparative genomic of the common voles, the phylogenetic relationships between most of the Palearctic, or the Nearctic, or the Palearctic and the Nearctic species groups, are still quite uncertain.

The facts and the arguments presented above, make us suppose that, though being undoubtedly related forms of the same evolutionary level, the hypothetical ancestors to the advanced living common voles were much more ancient or (and) might have initially possessed a larger amount of genomic divergence between each other, than the forms of the A. pliocenicus complex. Thus, on the one hand, the extent of "phenomo-genomic" homology between those ancestors was presumably enough to channel under the similar environmental conditions their homologous morphogenetic pathways to the Microtus-like level of organization. On the other hand, the terms and the rates of the "genomic divergence", as well as its amount, that had already been accumulated between the ancestral groups by the time of their "departure" for the Microtus level, could mould such uncertain pattern of "molecular" phylogeny, which was shown by the data on the cytochrome $b$ gene in the living Microtus-like species. Having summarized all those speculations we proposed a new scenario of mi- 
crotines' evolution (Golenishchev \& Malikov, 2004) according to which: 1) the ancestors to all the living Nearctic Microtus-like voles, dispersed to America from Eurasia before the Quaternary, being at the Mimomys evolutionary level; 2) the amount of divergence between the Mimomys ancestors to the main moleculargenetic Microtus clades was considerably larger than it is used to be between any sibling species; and 3) in both of the continents the Mimomys lineages had independently evolved into the clades of the living Microtuslike species via the Allophaiomys level of development. Our mode of thinking was influenced by a lump of quite old ideas, among which there were: E.R. Lankester's view, that "...under the term "homology" evolutionists have described and do describe two kinds of agreement - the one, now proposed to be called "homogeny", depending simply on the inheritance of a common part, the other, proposed to be called "homoplasy", depending on a common action of evoking causes or molding environment on such homogenous parts, or on parts which for other reasons offer a likeness of material to begin with" (Lankester, 1870: 42) (cited after Hall, 2003: 414); N.I. Vavilov's law of homologous series in variation (Vavilov, 1920); G.G. Simpson's comprehension of parallelism as "...the development of similar characters separately in two or more lineages of common ancestry and on the basis of, or channeled by, characteristics of that ancestry" (Simpson, 1961: 78) (cited after Hall, 2003: 420) and his approach to the relationships between homology, convergence, and parallelism, according to which "especially among more nearly related groups, the convergence is likely to involve homologous structures, as is also true of parallelism" (cited after Hall, 2003: 420); N.N. Vorontsov's idea, that a group, which has emerged in the result of the parallel evolution by means of natural selection of homologous mutations, should not be considered as a polyphyletic one, "because it is the parallel development on the base of the homologous mutating the descendants of some different lineages, which had quite considerably diverged from each other some when, have a tremendous capacity for, that was caused by similarity between the genotypes of the ancestors, and hence the common origination of the latter" (Vorontsov, 1966); B.K. Hall's notion about the convergent and at the same time parallel formation, according to which "Such overwhelmingly convergent evolution may reflect independent evolution when assessed at the level of the phenotypic character. At a deeper level of analysis, it yields insights into the evolution of the ancient genetic pathways and/or developmental processes that underlie character evolution, whether those characters are homologous or homoplastic" (Hall, 2003: 427). So, we accept synapomorphy not only as some unique state that is shared by all representatives of a monophyletic taxon with their common ancestor, in which such character had already been developed. It is also any morphogenetic "ambition" in common, which is based on the "phenomogenomic" homology the descending lineages share with each other, owing to their common origination. Such homologous evolutionary potency can be independently realized in different representatives of the group, especially if they pass through the same environmental history. In such case, the lineages of the same morphogenetic level, which have independently passed through the same "developmental conduit" (Martin \& Tesakov, 1998), are to be lumped into a natural group, because that "conduit" was determined by the "phenomo-genomic state" of their common ancestor, no matter it was a species or a monophyletic group of a higher taxonomic rank. As concerns the Palearctic and Nearctic common voles, they manifest synapomorphy of such kind not only in the form of Microtus-like state of morphology, but in a homoplastic morpho-ecological radiation. Thus, we consider the voles of the tribe Microtini as a natural group, though their main subdivided lineages are thought to have independently got to the Microtus-like morphogenetic state from the presumably Mimomys evolutionary level of their hypothetical common ancestor.

In the light of the recent data on molecular genetics, the taxonomic structure of the tribe Microtini obviously needs changing. Each of the reliable "molecular" clades should have a definite taxonomic rank according to the hierarchy of their phylogenetic relations. However, as it was mentioned above, the problem is that the modern data on molecular genetics and comparative genomics of the common voles provide a lack of information about phylogenetic relations between the most of the reliably monophyletic groups. Nevertheless, we consider that some preliminary steps towards the taxonomic revision of the Microtini can be made even now. As far as the Palearctic clades of the grey voles, which were considered as subgenera of the genus Microtus, turned out to diverge from each other no less, than from the Nearctic branches, each of them seems likely to need a rank of a distinct genus. All the American forms can be conditionally lumped together into the genus Mynomes Rafinesque, 1817, where the forms, which have been regarded as the Nearctic representatives of the subgenus Microtus should be considered to comprise the nominative subgenus Mynomes of the same genus. The latter change, concerning the subgeneric name was already proposed by Pavlinov (2003). The American narrow-skulled voles My. (St.) miurus and My. (St.) abbreviatus, which are mentioned above as Nearctic vicariants of $M$. (St.) greglis can also be separated into a distinct subgenus.

\section{Systematic interpretation}

Order Rodentia Bowdich, 1821

Family Cricetidae Fischer, 1817

Subfamily Arvicolinae Gray, 1821

Tribe Microtini Miller, 1886

Genus Mynomes Rafinesque, 1817

Vocalomys Golenishchev \& Malikov, subgen. nov.

Type species: Microtus miurus Osgood, 1901

Diagnosis: Voles of medium size with thick fur; tail short, bicoloured; dark stripe on head and anterior back 

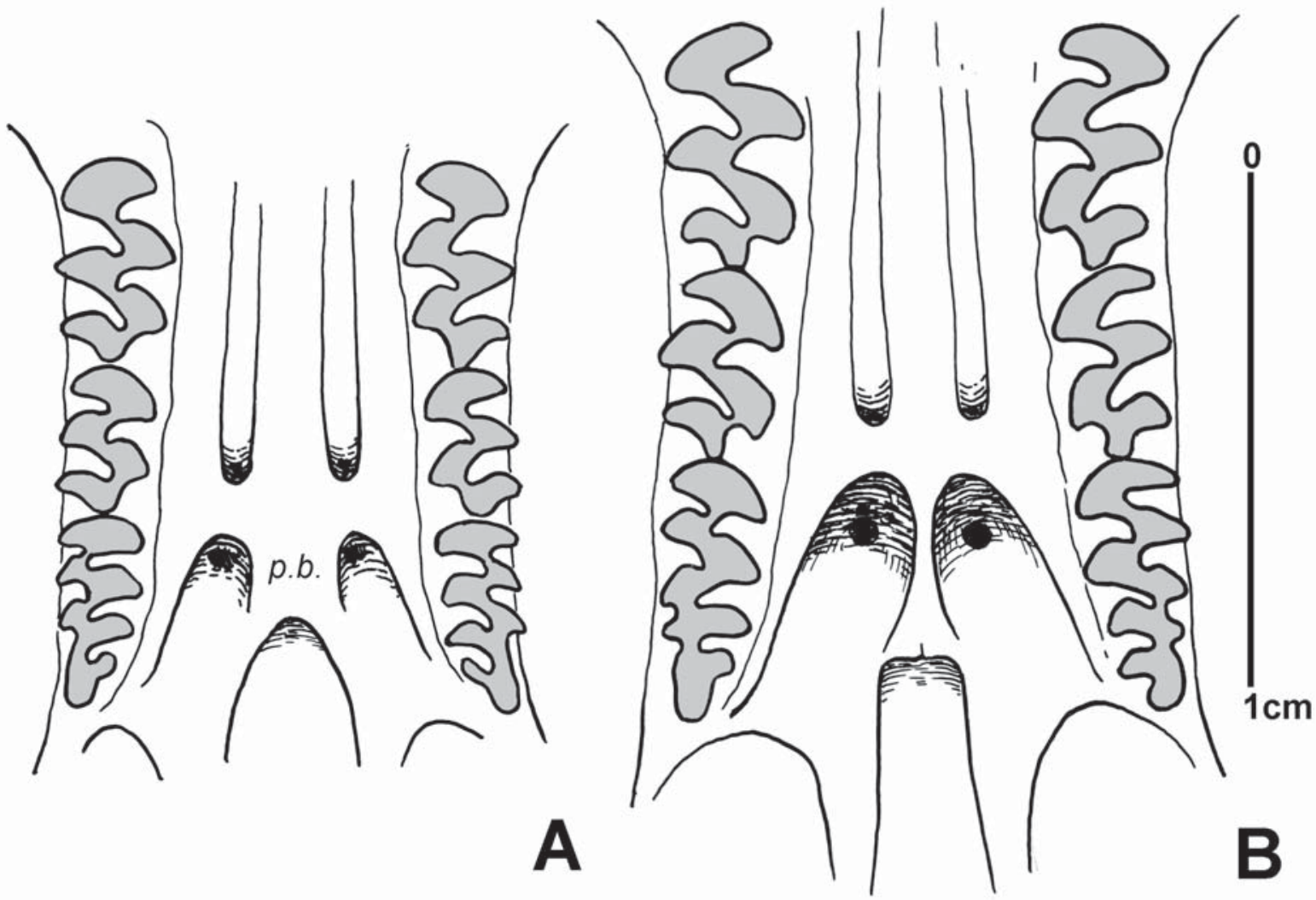

Figure 1. Palatal region of the skull in ventral view showing variation in the structure of the palatine bridge in Mynomes (Vocalomys) miurus, ZIN 40769 (A) and Microtus (Stenocranius) gregalis, ZIN 25399 (B).

Abbreviation: p.b. - palatine bridge. Scale bar is $1 \mathrm{~cm}$.

undeveloped; skull narrow with high braincase, narrow interorbital space, and well developed longitudinal crest. Skull shape similar to that of Palearctic M. (St.) gregalis; bony palate bridge broad and short; auditory bullae small, mastoids not enlarged. Paraconid section of $\mathrm{m} 1$ with second lobe complete and the lateral triangle completely isolated from anterior lobes; opposite triangles at base of paraconid isolated and have alternate position. Baculum large, the width of its base $30 \%$ of its total length and about $70 \%$ of the length of its column; the shoulders of the base either perpendicular to the column, or slanted; the lateral digital processes of the distal baculum either absent or not ossified for a long time as well as in the other Mynomes. Eight mammillae. $2 n=54$.

Differential diagnosis: Differs from all the other Nearctic voles in that it has narrower skull with the most narrow interorbital space and a higher braincase. The most of the morphological characters are plesiomorphic to those of the Palearctic subgenus Stenocranius. The Nearctic genus differs from its Palearctic vicariant in: 1) more simplified palate structure: smaller posterior palatal fossae together with shorter and broader palatal bridge (Fig. 1);2) presence of distinct apertures in pterygoid bones (Fig. 2); 3) more complex paraconid with two complete lobes instead of 1.5 ones in Stenocranius, and "smiling" unpaired anterior loop (Fig. 3); 4) wider base of the baculum, which in the American species is about $70 \%$ of the column's length, while in the Eurasiatic one is no more, than $50 \%$.
Species included: Type species only (including $M y .(V$. abbreviatus Miller, 1899)..

Distribution: In Alaska up to the Mackenzie River, in the East and up to $\mathrm{N} 60^{\circ}$ latitude in the South; the Hall and St. Matthew islands in the Bering Sea.

The biotops and the mode of life: Semi-subterranean forms, inhabitants of tundra and meadows in the mountains and in the plains. Those voles are known to store the green parts of herbs in small hays. Because of its characteristic chirp the American narrow-skulled vole is called "singing vole".

Etymology: From Latin vocalis, singing.

\section{The narrow-skulled voles as a life form: the evolutionary integrity of adaptive shifts and their initially inadaptive consequences}

Some authors consider the narrowness of the skull as a direct adaptation of that life form to permafrost, where there are a lot of narrow splits (Gromov \& Polyakov, 1977). As it was mentioned above, from our point of view, such amazing similarity in morphology between those vicariants is the result of the parallelconvergent evolution under the similar environmental conditions at the base of their phenomo-genomic homology. At the same time, the idea about the natural 

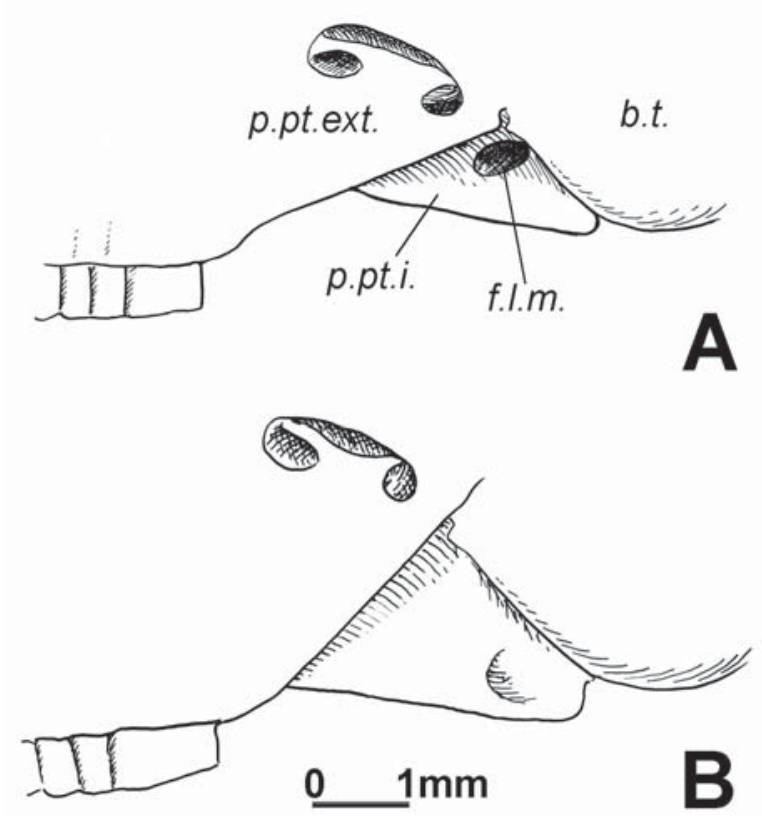

Figure 2. Lateral view of the skull showing structure of the processus pterigoideus internus of the basisphenoid in $M y$ nomes (Vocalomys) miurus, ZIN 71075 (A) and Microtus (Stenocranius) gregalis, ZIN 25399 (B).

Abbreviations: b.t. - bulla tympanica; f.l.m. - foramen lacerum medialis; p.pt.ext. - processus pterigoideus externus; p.pt.i. processus pterigoideus internus. Scale bar is $1 \mathrm{~mm}$.
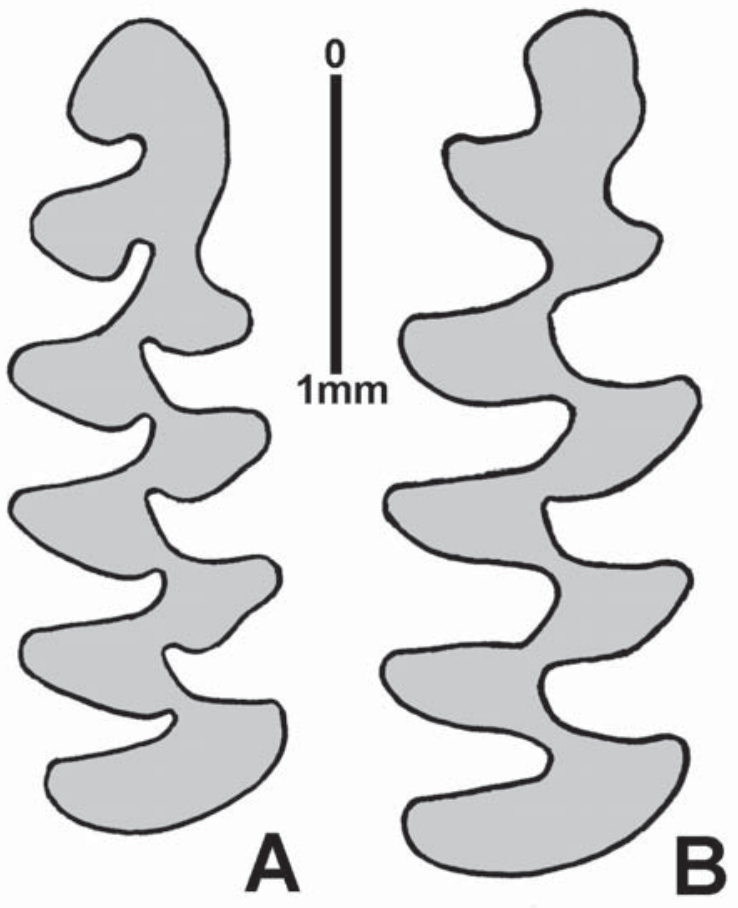

Figure 3. Occlusal view of $\mathrm{m} 1$ in Mynomes (Vocalomys) miurus, ZIN 40769 (A) and Microtus (Stenocranius) gregalis, ZIN 20097 (B). Scale bar is $1 \mathrm{~mm}$. selection that was initially directed towards the narrowness of skull seems us to be very naive, because it absolutely ignores the integrity of evolution. As early as in 1930-s it was already clear to D.N. Kashkarov, that most of the features, especially those ones, which are used in the identification keys, are of inadaptive nature, being a kind of stable "fellow-travelers" of the adaptive evolution as an integral process (Kashkarov, 1939). As in the result of the ontogenetic shifts, such inadaptive "coaches" are attached to the "locomotive" of the integral adaptive development, no wonder, that sooner or later they can emerge some serious problems for the evolutionary future of their owners (Chaikovsky, 2003). That's why evolution, as an integral process, is synergies between direct adaptations and adaptations to their stable inadaptive consequences (Malikov et al., 2006). As concerns the narrow-skulled voles as a life-form, their adaptive evolution under subarctic or alpine environmental conditions with extremely short periods of vegetation, low winter temperatures and a danger of summer droughts within the southern part of the Palearctic range, was directed to early sexual maturation that gives an opportunity to produce the maximum amount of offspring during the very short optimal season. For example in $M$. (St.) gregalis a pregnant female can be 12-13 days old (Chentsova, 1969).

The differences in the rates of growth and ontogenetic development are well known not only for distinct species (Golenishchev, 1982; Meyer et al., 1996) but for the geographical populations of the same species (Shvarts, 1980). For example, M. (St.) gregalis major Ognev, 1923 from Yamal Peninsula is characterized by considerably higher rate of growth, than the nominative subspecies from the southern part of the range (Pokrovsky \& Bolshakov, 1979).

The comparison between the rate of growth of $M$. (St.) gregalis (Golenishchev \& Petrovskaya, 2002) and that of M. mujanensis Orlov \& Kovalskaja, 1975 (Meyer et al., 1996), which are of a quite similar size, showed that in the narrow-skulled vole the condylobasal length intensively enlarged up to the age of 1 month, while in the second species by the age of 3 months that process was almost finished. At the same time in $M$. (St.) gregalis the zygomatic width starts enlarging slowly by the age of 3 months, and in $M$. mujanensis it enlarges intensively up to the age of 5 months.

The sexual maturation is known to reduce the rate of growth. As far as M. (St.) gregalis is concerned, it was reported to stop growing and developing under unfavorable conditions, and then rapidly start those processes.

So we suppose that early sexual maturation of the narrow-skulled voles led to a very rapid longitudinal growth of the skull that is needed for achieving the optimal total size by the beginning of reproduction. At the same time, the high rates and early terms of the skull's longitudinal growth leave a lack of bioenergetics resources for increasing of the skull width. Further that initially inadaptive, though inevitable, shift in proportions might have become adopted to the narrow splits of the permafrost. 
ACKNOWLEDGEMENTS. We are grateful to Dr. A. Tesakov (Geological Institute RAS, Moscow), Dr. V. Lebedev (Zoological Museum of Moscow University), Dr. A. Bochkov (Zoological Institute RAS, St. Petersburg), and Dr. A. Pesenko (the same institute) for valuable consultations and critical remarks. The work was supported by the "Biodiversity Program" of the Russian Academy of Sciences.

\section{References}

Angermann R. 1973. [Homologous variability of molars in voles (Microtinae)] // Vorontsov N.N. (ed.). [Problems of Evolution]. Novosibirsk: Nauka. T.3. P.104-118 [in Russian, with English summary].

Chaikovsky Yu.V. 2003. [Evolution. Issue 22]. Moskva: Tsentr sistemnyh issledovanii IIET RAN. 472 p. [in Russian].

Chaline J., Brunet-Lecomte P., Montuire S., Viriot L. \& Courant F. 1999. Anatomy of the arvicoline radiation (Rodentia): palaeogeographical, palaeoecological history and evolutionary data // Annales Zoologici Fennici. Vol.36. No.4. P.239-267.

Conroy C.J. \& Cook J. A. 2000. Molecular systematics of a Holarctic rodent (Microtus: Muridae) // Journal of Mammalogy. Vol.81. No.2. P.344-359.

Chentsova N.Yu. 1969. [On the adaptive role of inbreeding in small rodents] // Zoologicheskii Zhurnal. T.48. No.5. P.734-745 [in Russian].

Ellerman J.R. 1941. The Families and Genera of Living Rodents. London: British Museum (Natural History). Vol.2. 690 p.

Ellerman J.R. \& Morrison-Scott T.S. 1951. Checklist of Palaearctic and Indian Mammals, 1758 to 1946. London: British Museum (Natural History). 810 p.

Golenishchev F.N. 1982. [The grey voles (subgenus Microtus, the "maximowiczii" group) of the East Siberia and the Far East]. Avtoreferat Candidatskoi Dissertatsii. Leningrad. 23 p. [in Russian].

Golenishchev F.N. \& Malikov V.G. 2004.Palaearctic and Nearctic common voles (Rodentia, Arvicolini): evolution and outlook // Proceedings of the Zoological Institute RAS. Vol.300. P.83-90.

Golenishchev F.N. \& Petrovskaya N.A. 2002. Geographic variation of Microtus (Stenocranius) gregalis Pall., 1779 // Golenishchev F.N. \& Nikulina N.A. (eds.). [Theriological Investigations]. Sankt-Peterburg: Teriologicheskoe Obshchestvo. T.1. P.17-34 [in Russian, with English summary].

Golenishchev F.N. \& Sablina O.V. 1991. On taxonomy of Microtus (Blanfordimys) afghanus // Zoologicheskii Zhurnal. T.70. No.7. P.98-110 [in Russian, with English summary].

Graf J.-D. 1982. Genetique biochimique, zoogeographie et taxonomie des Arvicolidae (Mammalia, Rodentia) // Revue Suisse de Zoologie. T.89. No.3. P.749-787.

Gromov I.M. 1972. [The superspecific systematic categories in the subfamily Microtinae] // Sbornik Trudov Zoologicheskogo Museya MGU. T.13. P.8-32 [in Russian].

Gromov I. M. \& Polyakov I. Ya. 1977. [The Fauna of the USSR. Mammals. T.3. Vyp.8. Voles]. Leningrad: Nauka. 504 p. [in Russian].
Hall B.K. 2003. Descent with modification: the unity underlying homology and homoplasy as seen through an analysis of development and evolution // Biological Reviews. Vol.78. No3. P.409-433.

Hoffman R.S. \& Koeppl J.W. 1985. Zoogeography // Tamarin R.H. (ed.). Biology of New World Microtus. Special Publication American Society of Mammalogists. No.8. P.84-115.

Hooper E.T. \& Hart B.S. 1962. A synopsis of Recent North American microtine rodents // Miscellaneous Publications Museum of Zoology of University of Michigan. Vol.123. P.1-57.

Jaarola M., Martínková N., Gündüz I., Brunhoff C., Zima J., Nadachowski A., Amori G., Bulatova N.Sh., Chondropoulos B., Fraguedakis-Tsolis S., Gonzales-Esteban J., Lopez-Fuster M.J., Kandaurov A.S., Kefelioglu H., Mathias M.L., Villate I. \& Searle J.B. 2004. Molecular phylogeny of the speciose vole genus Microtus (Arvicolinae, Rodentia) inferred from mitochondrial DNA sequences / / Molecular Phylogenetics and Evolution. Vol.33. No3. P.647-663.

Kashkarov D. N. 1939. [Whether evolution is adaptive and what the specific characters are] // Zoologicheskii Zhurnal. T.18. No4. P.612-630 [in Russian].

Lance E. \& Cook J.A. 1998. Biogeography of tundra voles (Microtus oeconomus) of Beringia and the southern coast of Alaska // Journal of Mammalogy. Vol.79. No 1. P.5365.

Lankester E.R. 1870. On the use of the term homology in modern zoology, and the distinction between homogenetic and homoplastic agreements // Annals and Magazine of Natural History, Series 4. Vol.6. No.31. P.34-43.

Malikov V.G., Zakirova V.R. \& Golenishchev F.N. 2006. [The baculum in mammals as an emergent structure at the initial stages of ossification] // Otchetnaya Nauchnaya Sessiya po Itogam Rabot 2005 goda. Zoologicheskii Institut RAN. Tezisy Dokladov. P.27-28 [in Russian].

Martin R.A. 1987. Notes on the classification and evolution of some North American fossil Microtus (Mammalia, Rodentia) // Journal of Vertebrate Paleontology. Vol.7. No3. P 270-283.

Martin R.A. 1995. New middle Pleistocene species of Microtus (Pedomys) from the southern United States, with comments on the taxonomy and early evolution of $P e$ domys and Pitymys in North America // Journal of Vertebrate Paleontology. Vol.15. No1. P.171-186.

Martin R.A. 1998 Time's arrow and evolutionary position of Orthriomys and Herpetomys // Paludicola. Vol.2. No.1. P.70-73.

Martin R.A. \& Tesakov A. 1998. Introductory remarks: Does Allophaiomys exist? // Martin R.A. \& Tesakov A. (eds.). The Early Evolution of Microtus. Paludicola. Vol.2. No1. P.1-7.

Meyer M.N., Golenishchev F.N., Radjabli S.I. \& Sablina O.V. 1996. [Voles (Subgenus Microtus Schrank) of Russia and Adjacent Territories]. Trudy Zoologicheskogo Instituta RAN. T.232. 320 p. [in Russian].

Modi W.S. 1987. C-banding analyses and the evolution of heterochromatin among arvicolid rodents // Journal of Mammalogy. Vol.68. No.3. P.704-714. 
Modi W.S. 1996. Phylogenetic history of LINE-1 among arvicolid rodents // Molecular Biology and Evolution. Vol.13. No5. P.633-641.

Modi S.W., Serdyukova N.A., Vorobieva N.V. \& Graphodatsky A.S. 2003. Chromosomal localization of six repeated DNA sequences among species of Microtus (Rodentia) // Chromosome Research. Vol.11. No.7. P.705713.

Musser G.G. \& Carleton M.D. 2005. Superfamily Muroidea // Wilson D.E. \& Reeder D.M. (eds.). Mammal Species of the World. A Taxonomic and Geographic Reference. Third edition. Baltimore: The Joins Hopkins University Press. Vol.2. P.894-1531.

Nadachowski A. \& Zagorodnyuk I. 1996. Recent Allophaiomys-like species in the Palearctic: Pleistocene relicts or a return initial type // Acta Zoologica Cracoviensia. Vol.39. No1. P.387-394.

Pavlinov I.Ya. 2003. Systematics of recent mammals // Sbornik Trudov Zoologicheskogo Museya MGU. T.46. P.1-293 [in Russian].

Pavlinov I.Ya. \& Rossolimo O.L. 1987. [The systematics of mammals] // Sbornik Trudov Zoologicheskogo Museya MGU. T.25. Moskva: Izdatel'stvo Moskovskogo Universiteta. P.1-284 [in Russian].
Pokrovsky A.V. \& Bolshakov V.N. 1979. [Experimental Ecology of Voles]. Moskva: Nauka. 147 p. [in Russian]. Repenning C.A. 1983. Pitymys meadensis from the Valley of Mexico and the classification of North American species of Pitymys (Rodentia, Cricetidae) // Journal of Vertebrate Paleontology. Vol.2. No.4. P.471-482.

Repenning C.A. 2001. Beringian climate during intercontinental dispersal: a mouse eye view // Quaternary Science Reviews. Vol.20. No.1. P.25-40.

Repenning C.A., Feifar O. \& Heinrich W.-D. 1990. Arvicolid rodent biochronology of the northern hemisphere // Feifar O. \& Heinrich W.-D. (eds.). Internetional Symposium on the Evolution, Phylogeny and Biostratigraphy of Arvicolids (Rodentia, Mammalia). Munich: Pfiel-Verlag. P.385-418.

Vavilov N.I. 1920. [The Law of Homologous Series in Variation] // [Transactions of the Third Congress on Plant Cultivation]. Saratov. 16 p. [in Russian].

Shenbrot G.I. \& Krasnov B.R. 2005. An Atlas of the Geographic Distribution of the Arvicoline Rodents of the World (Rodentia, Muridae: Arvicolinae). Sofia, Moscow: Pensoft. 350 p.

Shvarts S.S. 1980. [The Ecological Regularities of Evolution]. Moskva: Nauka. 278 p. [in Russian]. 